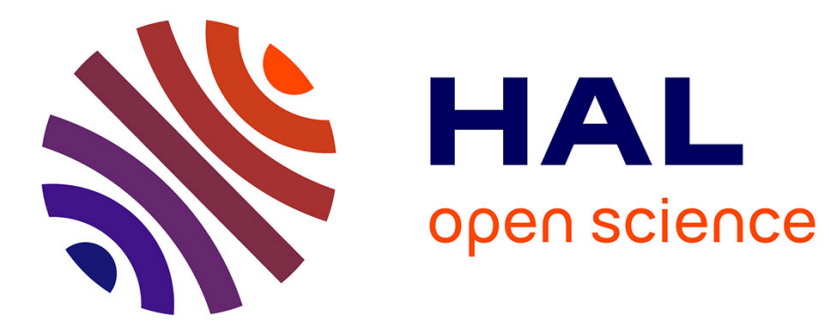

\title{
The Biography of a Magar Communist
}

Anne de Sales

\section{To cite this version:}

Anne de Sales. The Biography of a Magar Communist. David Gellner. Varieties of Activist Experiences in South Asia, Sage, pp.18-45, 2010, Governance, Conflict, and Civic Action Series. hal00794601

\section{HAL Id: hal-00794601 \\ https://hal.science/hal-00794601}

Submitted on 10 Mar 2013

HAL is a multi-disciplinary open access archive for the deposit and dissemination of scientific research documents, whether they are published or not. The documents may come from teaching and research institutions in France or abroad, or from public or private research centers.
L'archive ouverte pluridisciplinaire HAL, est destinée au dépôt et à la diffusion de documents scientifiques de niveau recherche, publiés ou non, émanant des établissements d'enseignement et de recherche français ou étrangers, des laboratoires publics ou privés. 
Chapter 2

\title{
The Biography of a Magar Communist
}

\author{
Anne de Sales
}

Let us begin with the end of the story: Barman Budha Magar was elected a Member of Parliament in 1991, one year after the People's Movement (jan andolan) that put an end to thirty years of the Partyless Panchayat 'democracy' in Nepal. He had stood for the Samyukta Jana Morcha or United People's Front (UPF), the political wing of the revolutionary faction of the Communist Party of Nepal, or CPN (Unity Centre). ${ }^{1}$ To the surprise of the nation, the UPF won 9 seats and the status of third-largest party with more than 3 per cent of the national vote. However, following the directives of his party, ${ }^{2}$ Barman, despite being an MP, soon went underground until he retired from political life at the time of the People's War in 1996.

He does not question the guerrilla war launched by the CPN (Maoist), to which he claims a moral attachment. ${ }^{3}$ He gives his age (he was 66 years old at the time - no longer appropriate to a clandestine lifestyle) as the reason why stopped being politically active. Now in his late

\footnotetext{
${ }^{1}$ After 1990, several radical communist groups professing Maoist thought, such as CPN (Masal, the Mohan Bikram Singh group) and CPN Mashal (Mohan Vaidya group) among others, were brought together under the Unity Centre appellation. In 1995 the leader of the Unity Centre, Pushpa Kamal Dahal (alias Prachanda) seceded and formed yet another group, the CPN (Maoist). For a lucid recent discussion of the political parties in Nepal, see Hachhethu (2006).

2 The ostensible purpose of the revolutionaries in contesting the parliamentary elections of 1991 and the local elections of 1992 (where they were seen to be even more successful and therefore a serious threat to the Nepali Congress, traditionally dominant in the west of the country) was to "expose the sham of parliamentary democracy" (Hachhethu, 2006: 10).

3 This paper is based on about ten interviews with Barman, who agreed to my proposal to write his biography in 2005. The trip to Nepal was financed by the MIDEA Programme (www.uni-bielefeld .de/midea) and I thank David Gellner and Joanna Pfaff-Czarnecka for making this possible.
} 
seventies, he lives in his daughter's house near Kathmandu. Seated cross-leggèd on a carpet, invariably wearing the short home-woven kilt characteristic of Magar dress or wrapped in a blanket when it is cold, he looks like any elderly villager, taking care of his grandchildren and walking his dogs. However, the numerous visits that he receives from journalists and politicians bear witness to the fact that he was a key character in establishing communism in Rolpa and Rukum, the rebels' base. ${ }^{4}$ As preparation for elections to the Constituent Assembly gradually got under way following the Second People's Movement of 2006, his presence as an honoured guest at Maoist meetings in what had become known as the Magarant Autonomous Region illustrates the iconic quality he has retained over the years as a local leader.

Unlike most political activists, who received a formal education and who developed their careers by remaining close to urban centres, most of Barman's political life remained anchored in his rural homeland. Apart from brief trips to India, he never wished to leave Nepal and indeed remained in his home territory. Nepal offered a large enough playground to satisfy his insatiable curiosity, and his ambition was to change his own society. How did it all begin? The growing politicization of the country over the previous fifty years, and an early communist presence in the area, helped Barman to find new expression for his opposition to what he initially conceptualized simply as unjust situations that demanded to be redressed. This study aims to retrace the process by which Barman's political awareness emerged from local conflicts and how he helped in turn to adapt communist propaganda to local realities. The following account, focusing on Barman's political awakening, will concentrate on the period preceding the People's War. The question that underlies it concerns the extent to which he became a modern activist or remained a traditional local leader.

As a Communist and a Magar, Barman stands at the crossroads of two different, even potentially antagonistic, movements that have dominated Nepalese political life since 1990:

\footnotetext{
${ }^{4}$ Ogura's (2007) investigation of the roots of the Maoist movement in Rolpa and Rukum districts confirms Barman's instrumental role. I take this opportunity to thank this author for making her work available to me before publication. Robert Gersony's report (2003) is another comprehensive and generally reliable study, and can be used independently of his consultancy analysis.
} 
the Communists, including the Maoists, aim at the ideal of a nation of equal citizens through the 'class struggle', irrespective of all distinctions of caste and ethnic group. By contrast, ethnic movements fight for the recognition of the various jatis, or nationalities, and the eventual establishment of autonomous regions. This debate between the class- and ethnicitybased principles of political struggle will be discussed further towards the end of this chapter. Barman's biography, as recounted by him, should help us to understand how the potential contradiction between such principles are not only conceived but also experienced by a political actor in a rural area, which has been at the forefront of the media over the past fifteen years.

The fact that Barman belongs to the Kham-Magar-speaking minority is not insignificant in this respect. The 40,000 speakers of this Tibeto-Burman language have long been considered 'poor relatives' of the Magar proper, the largest ethnic group in Nepal (1.62 million) Post1990 publications concerned with the reconstruction of the history of the Magars present the original homeland of the Magar as the medieval Magarant, covering the mountainous area between the Kali Gandaki and Bheri rivers. ${ }^{5}$ The western region, Athara Magarant ('the Magar country of the Eighteen [Clans]'), is distinguished from the eastern region or Bahra Magarant ('the Magar country of the Twelve [Clans]'). The inhabitants of Bahra Magarant have been generally more exposed to national politics; they have lived for generations in multi-caste villages and provided soldiers to the British Army's Brigade of Gurkhas, whereas the Kham speakers, inhabitants of the Athara Magarant, remained further away from communication centres. ${ }^{6}$ The Kham speakers are grouped together in fourteen Village Development Committees on the upper hills of Rukum and Rolpa districts in Rapti zone. With the sole exception of two service castes, Blacksmiths (Kami) and Tailor-Musicians (Damai), who have been attached to their Magar masters (bista) for generations, this enclave has not attracted any other castes in search of land. On the chequerboard of ethnic politics they represent a minority within the Magar group and a backward minority in the eyes of the Magar elite.

\footnotetext{
${ }^{5}$ These publications, all in Nepali, have been analysed by Marie Lecomte-Tilouine (2004, in press) and Makito Minami (2006).

${ }^{6}$ The Gurkhas started to recruit in the Kham Magar area only after 1985.
} 
Due to the constraints of this paper, I will simply mention two striking features of Barman's narrative. Barman and I initially chose to proceed chronologically rather than topically, but this approach soon had to be abandoned. Barman's memories moved naturally along the paths he had walked all his life. His biography would therefore more accurately be organized along routes: routes of transhumance when he was a shepherd; routes to the district headquarters for his many trials; to Kathmandu in search of a hospital for his wife; to the bazaar in the south where he sold hashish; and finally to the villages he visited during his political campaigns. The needs of exposition require the information to be reorganized along more chronological lines, but we should bear in mind that Barman's narrative is structured as a journey. Another remarkable feature is Barman's oratorical skill. He paces the telling of his stories with proverbs - or what sound like proverbs, although they may have been invented on the spot - and with quotations from local songs that encapsulate the moral of his story and stress its point. ${ }^{7}$ Born in a society of oral tradition, Barman excels in storytelling and this talent no doubt contributed to his success as a leader. He is able to draw from a shared folklore and speaks to people in a language with which they are familiar.

These remarks about Barman's account do not take us away from the main theme of this volume: that is, activism. The notion of activism is concerned with the ambition to transform the world and mobilize people around new ideals. One characteristic of this notion, as a sociological phenomenon, is that it stands at the interface of the subjective and the social: it combines the transformation of the world or society with the transformation of the activist as a person, of his or her self. Activists venture on to a frontier between the world that they strive to leave behind and their vision of a new world. It is not irrelevant to the subject that, apart from hagiographies, the few modern biographies available in Nepal concern political activists. ${ }^{8}$ They see themselves as part of history in the making and their trajectories acquire a

\footnotetext{
${ }^{7}$ March (2002) found the same importance of songs in her work on Tamang women's lives.

${ }^{8}$ Among the few biographies available in English, see Fisher (1997) on Tanka Prasad Acharya, the founder of the first political party in Nepal and his wife; Aziz (2001) on the life of Yogamaya and Durga Devi, two social activists under the Ranas; Two autobiographies, one by B.P. Koirala, the leader of the Nepali Congress translated into English in 2001 and one by Durga Pokhrel, a human right activist under the Panchayat system
} 
reflexive dimension. ${ }^{9}$ Given that such activities developed in Nepal relatively recently hardly three generations ago - this transformation affected activists of Barman's generation even more radically.

In the following section a sketch of Barman's life in Rana times will show the ground that he has covered. The second section will give an account of Barman's political awakening following the first Nepalese revolution in 1950-51. The third and last section will describe the deepening of Barman's commitment under the three decades of Partyless Panchayat that led to the second Nepalese revolution in 1990.

\section{Before 1950: the Thakuri conquest and the Rana patrimonial State.}

Barman was born in 1930 in the village of Thabang (or Thawang), in the north of Rolpa district. At that time the area was the western canton (thum $)^{10}$ of Pyuthan district and was locally called kalashes, 'the black heights', the eastern canton being called gorashes, 'the white heights'. Nepali shes designates more precisely a high remote place, with connotations of being somehow residual. This could not better express the feeling of the inhabitants, among whom the Kham Magar constitute the majority.

The Thabang area was covered with forest and the villagers had to provide forced labour (jara) to the Pyuthan authorities. In their case, this meant making charcoal. The famous pyuthane nal, a type of gun, needed fuel to melt metal for the barrel and good walnut wood for the stock. Once the area was cleared and the wood burnt, it was converted into farming land. In 1848, the Ranas ${ }^{11}$ married one of their daughters, Chandra Devi, to Indra Bahadur

\footnotetext{
(Pokhrel and Willett, 1996). On the subject of the biography as a literary genre in South Asia, see the introduction to Fisher (1997).

9 This point is developed by Levy (1998).

${ }^{10}$ The thum was an administrative unit encompassing several hamlets, themselves reorganized into named villages and under the jurisdiction of an official from the central government. It usually had natural frontiers and formed a ritual unit (Gaborieau, 1978).

${ }^{11}$ The Ranas were a powerful family who ruled the country as dynastic Prime Ministers from 1846 to 1951. Under their dictatorship the king's role was strictly ceremonial.
} 
Shahi ('Captain' to the villagers), the grandson of the last Thakuri king of Rukum. ${ }^{12}$ The bride's dowry was Thabang, along with Bahunthana near Rukumkot, as freehold land (birta). ${ }^{13}$ What this meant for the villagers was that now they owed tax to the birta-holder rather than directly to the King.

Indra Bahadur joined the Nepalese army (hence his title of Captain) and entrusted his younger brother, Upendra, to collect the taxes in the area. Like many officials in such a position, Upendra had a reputation for extorting money from villagers with the help of local headmen, or mukhiyas, whom he appointed to collect taxes in their respective villages. It seems that the headmen changed often and that this was a source of conflict among Thabangis. Other villages under the more common raikar land tenure system also suffered from their headmen, who were entitled to collect taxes for the government. However, even if conflicts were frequent, this office usually fell to the oldest member of the local founding clan and was not the object of intense competition, as seems to have been the case in Thabang. The intrusion of an influential Thakuri to back up his chosen headman could not but make things worse. Birta status, unique to Thabang among the Kham-Magar-speaking villages, may well have played its part in the village's exceptional destiny as the Maoist 'capital'.

Barman was a long-awaited son. His parents, who had only daughters, begged the local god Braha to send them a son and sacrificed a ram at the top of Jaljala, one of the highest hills in Rolpa district. Until the Maoists banned this practice, hundreds, if not thousands, of ram sacrifices were made every year to this local god by people of all castes, some of whom came

\footnotetext{
${ }^{12}$ The traditional ruling families in the hills of Nepal are known as Thakuris. They claim descent from the Rajputs who fled to Nepal from Rajasthan to escape the Muslim invaders (14-16 $6^{\text {th }}$ century). According to Lokendra Bahadur Shah, a descendant of the Thakuri ruler whom I interviewed in 2005, his ancestors came from Jumla to settle in Rukumkot in the $14^{\text {th }}$ century and by trickery defeated the local king, Bokse Jar. Four centuries later, at the time of Bahadur Shah, the Thakuri kingdom joined the Gorkhali state. Although the Thakuri family had to give up its royal prerogatives, it kept a close alliance with the rulers of Nepal: if Indra Bahadur Shahi married a Rana, their grandson, Kumar Mohan Bahadur Shahi, married Princess Shobha, the younger sister of King Gyanendra. See Ogura (2007) for a more detailed account of the history of the ruling families of Rukum, although the scarcity of documents necessarily makes this a partial attempt.

${ }^{13}$ Birta refers to a privileged endowment of a land on which the king no longer claims rent. One of the first measures taken by the first elected government of Nepal in 1959 was to abolish this form of tenure. By contrast, raikar land tenure denotes leasehold land.
} 
from afar, to ask for offspring and prosperity. Barman associates the first syllable of his name, bar, with the 'blessing' or 'gift' granted by Braha to his parents.

The Maoists rebels were not mistaken in symbolically conquering Jaljala. A pillar to the memory of their martyrs was erected on the pass below the mountain top soon after the beginning of the People's War and the name appears in numerous propaganda songs. ${ }^{14}$ It is also used in association with the name of another high hill, Sisne, in Rukum district, and designates the first political campaign by the Maoists in 1995, Si-ja Abhiyan.

The pass and its small lake had already been the object of conflict among the gods. A legend tells how Satsalya, a deity coming from the west, wanted to fight with Braha on Jaljala. With the help of two Magar hunters, Braha defeated his competitor. He made the Magars his priests, or pujaris, confirming the pre-eminence of this group in the place. ${ }^{15}$ Although the identity of the divinity Satsalya is unclear, its western origin suggests a parallel between the conflict between the gods and the conquest of the local Magars by the Thakuri from Jumla. This would not be the first Nepalese case where the conquerors entrusted indigenous people with the worship of local gods. ${ }^{16}$

Barman's grandfather was the headman of a nearby village, Jurbang, while his father married in Thabang. Since his wife, Barman's mother, was the only daughter, the couple stayed in her parents' house. Being a 'house son-in-law' (ghar juwai) is poorly regarded among the Magars, as among other Nepalis. Moreover, among the Magars wife-takers have a lower status vis-à-vis their wife-givers, who remain their eternal creditors for having given their daughters away. This asymmetric relationship is less easily reversed when the son-in-law

\footnotetext{
${ }^{14}$ Some examples are given in de Sales (2003).

${ }^{15}$ The Braha priests are Thabangi, members of the Rokha clan. There are four main clans in Thabang; Rokha, Budha, Gharti, and Pun, but the first two outnumber by far the others. The clans (thar) are sub-divided into exogamous sub-clans.

${ }^{16}$ The most famous example is the worship of Mankamana, the goddess of the Gorkha's dynasty, that was entrusted to Magar priests. On the subject of the participation of indigenous populations in the state rituals of Nepal see Lecomte-Tilouine (2000).
} 
does not have his own space to be a father-in-law in his turn. Barman, the grandson of a headman, may have felt his ambitions thwarted by being the son of a 'house son-in-law'.

He was still a child when he was sent to look after his father's sheep, a flock of 300 to 400 , along with a hired shepherd. The transhumance routes cross the area from the high pastures in the north (well into Dolpo) to the south (as far as Dang, keeping to the ridges). The shepherds rarely stay in the village. They come down from the pastures to celebrate the two festivals of Dasai: Thulo Dasai in the autumn, when returning from the north, and Caite Dasai in the spring, when coming back from the south. Compared to the more sedentary villagers, they are known to be independent, free-spirited, and prone to fighting and gambling (although Barman was never attracted by gambling). They also have a great deal of free time. Barman taught himself how to read and write while he was looking after his animals. He learned the alphabet, drawing letters with a stone in the dust of the trail.

To conclude: Barman spent his formative years under the Rana dictatorship, a time when a Magar villager would have had very little prospect of political participation other than through being chosen as a tax collector by the local Thakuri. As the son of a 'house son-inlaw', he was unlikely to have been in a position to obtain even this position and Barman was more inclined to travel with his sheep.

\section{From village conflicts to political awareness: 1950-1959}

\section{Transhumance and the circulation of ideas}

The 'revolution of the year 7' (satsalko kranti), i.e. the revolution of 1950-51 that overthrew the Ranas, is a landmark in Barman's account. He remembers when he heard about the Congress for the first time, on his way down to Dang with his sheep:

I used to graze the sheep in Chalikot. Many people from different places would gather there, some with their sheep, some with their cows and buffaloes through the jungle. One day I heard people from Dang shouting: "Congress have come! Congress have come!" (Kangress ayo). I wondered what sort of people these were! I thought they might look different from us. Later I understood that leaders from Kathmandu had come to ask the people in Dang to join their group and protest against the Ranas. They were going around shouting: "Death to the Ranas, long live the Nepali Congress!" 
There are big landlords (jamindar) in Dang. The rumour was that some of them had fifty to sixty armed guards to protect them. Jaikku Prasad Bahun was one of them. He was very rich. Congress sympathizers raided his house. The Gaine musicians used to sing:

The Great King riding [in the]

Dang jungle

Grandfather Bahun Jaikku Prasad

How long [is his] beard! ${ }^{17}$

In the past only Tharus could live in the Tarai. Being autochthonous, they were immune to malaria. But gradually clever people from the hills, Bahuns and Chhetris, came down to buy land. The Tharus agreed to work on their fields and to divide the crops with their landlords. The landlords paid the taxes, something the Tharus were too poor to do. During the hot season they would carry all the food to their landlords who stayed in higher cooler places above Dang. They went back and forth like a mother bird feeding her fledglings; the landlords just stayed at home doing nothing. The Tharus are simple and docile people without any sense of revolt. Their landlords could beat or kill them, and they would say nothing. Their share of crops was not enough to feed them, so they had to borrow grain from their landlords and in this way would find themselves bound to them. For Maghe Sankranti, a big Tharu festival, the landlords would pretend to be generous and give them alcohol so that they would renew their promise to stay on the following year and work for them. In Rukum and Rolpa it is different: there are no landlords, and we work our own fields.

This account shows that the first revolutionary ideas circulated from the southern bazaars in the plains up to the northern hills through the transhumance routes. Barman takes up the analysis provided by the anti-Rana propaganda of the time: the appropriation by high-caste immigrants of the land of the indigenous Tharus, their gradual enslavement to their landlords and the trickery behind the yearly ritual through which the Tharus had their contract renewed. Barman also takes up the contrasted stereotypes respectively associated with the populations in the Tarai and in the hills. While the Tharus are said to be credulous and docile, and the Bahuns and Chhetris devious and experienced in dealing with the state, Barman by contrast remembers wanting to join the army of liberation, or mukti sena, in accordance with the warrior ideals conventionally associated with hill people. ${ }^{18}$ The army was the natural option for those hillmen who, apart from bringing some cash home, wanted to see the world beyond

\footnotetext{
${ }^{17}$ Shri Panc Maharaj Dhiraj sawari bhayo Dangko ghari ghari it supported K.I. Singh's attempted coup in January 1952 (Joshi and Rose, 1966: 88, 100; Whelpton, 2005: 89).
} 
their village. In fact, Barman was not drawn to this project by political motivations, but rather by curiosity about the outside world:

Once I ran away from the pastures to join the army of liberation, but the husband of my elder sister caught me on the way and forbade me to go. I wanted to see Kathmandu city and to study. I thought it was useless to remain a shepherd and look after animals all my life. But I did not have any political awareness (cetan) at that time, I just thought that it would be fun to travel.

\section{The shepherds' association}

A new headman, Krishna Bahadur Jhankri, himself the son of a previous headman of Thabang, was appointed in $1952 .{ }^{19}$ He was a sympathizer of the Nepali Congress and began to modernize the village. He tried to reform local customs, such as pig rearing, which he banned on sanitary grounds. This measure turned out to be unpopular among the Magars, who have a particular fondness for pork. The main problem, however, was that Krishna took advantage of his position as a tax collector. The freehold land privilege had not yet been abolished and the Thabangis were still required to satisfy the birta-holder in Rukumkot. In order to calculate the amount each had to pay, the village had been divided into two approximately equal halves, each half being sub-divided into five groups or divisions (khandas). These groups corresponded to ten exogamous lineages. It seems that the two halves were drawn up simply to provide some kind of demographic balance and to simplify the calculation of the taxes, with each lineage paying a fixed amount.

Until then the Thabangis had not taken into account the land survey (napi) documents of 1912, which were compiled under Prime Minister Chandra Sumshere Rana. On the basis of these documents, which specified the measurements of the fields and the names of their owners, Krishna Mukhiya questioned the amounts people used to pay. He then suggested to some villagers that they were entitled to contribute less, given the size or the category of their fields as specified in the documents. He encouraged others to claim their ownership of this or that field cultivated by somebody else. He introduced a different logic, based on individual

\footnotetext{
${ }^{19}$ Jhankri here does not designate the Nepali ritual specialist, but an exogamous lineage belonging to the Rokha clan, one of the four Kham-Magar clans along with the Budha, the Gharti and the Pun. Krishna Jhankri (Krishna Mukhiya) is mentioned briefly by Ogura (2007: 456-7).
} 
interest and conformity to written documents, in place of the lineage solidarity that had prevailed up till then.

What Krishna Mukhiya personally gained by sweeping the dust off these documents and creating havoc was the opportunity to appear as the saviour of the oppressed and, Barman suggested, to gain moral credit from those who ended up paying less. Barman openly expressed his discontent at what he saw as an attempt to gain the political high ground and led the opposition to Krishna Mukhiya: "I knew people were afraid of him because he was powerful - appointed by the Thakuri of Rukumkot - but I don't like people who lie and cheat. I don't like people looking down on others."

On the $1^{\text {st }}$ of Jeth, 2011 (June 1954) Barman formed an association of shepherds (gwala sanghatan) numbering about fifty to sixty men with a hard core of seven members. When they were not too far away from the village, the shepherds came down from the pastures at night and visited the villagers, inquiring about Krishna Mukhiya and encouraging people to oppose him. Numerous fights took place between Krishna's and Barman's groups. These fights remain vivid in Barman's memory and he enjoys recounting them:

Once we wanted to trap Krishna Mukhiya at home and force him to come out with his gun, so that we could then accuse him of having threatened us. We threw stones at his house and shot clay bullets with our slings. We did not let the public crier (katawal) approach the house and take his instructions from Krishna. Finally, Krishna came out with his gun. We were standing on the hill above the house, shouting in his direction and throwing out our chests, provoking him: "Here, here, shoot here!" Krishna's friends joined him and they ran after us. We escaped through the Blacksmiths' quarter then to the jungle. We ended up in Jurbang village, at the house of a friend called Manjit, where we stopped and had beer. Suddenly somebody rushed into the house and warned us: "Hey guys! Your old man is coming!" I remember Manjit, his nose in the bowl of beer. He did not know what to do, finish his beer or run with us! "Wait! Wait! I'm coming!" (laughs).

This was the beginning of a long walk to Pyuthan headquarters, where Barman and his friends had planned to bring a legal case against Krishna. The journey was slowed down by a search for money and a lack of food. When they finally arrived, they saw "people wearing suruwal" approaching. The sight of these Nepali trousers (loose in the seat and closefitting from the knees down), characteristic of government officials and high-caste people, made them run away, but they were finally caught: Krishna had preceded them and already 
registered a case against Barman for being a Communist. ${ }^{20}$ "I knew nothing about the Communist Party at the time", says Barman, "but I have learned."

\section{The accusation of communism}

The first thing Barman remembers after he and his two friends were arrested is that they were given a snack of soya beans. The provincial governor (bada hakim) was standing next to him and also popped a few roasted beans in his mouth. Barman looked at him and asked, "Do you also eat soya beans?" and the governor answered, "If we did not eat this, what would we eat then? We too can die of hunger." Barman did not expect this "important man" (thulo manche) to be such an ordinary human being, with the same needs and eating habits as himself, an ordinary villager. It must have been the first time (he was in his early 20s) that he had ever conversed with a government official: "For several days after this meeting my body was shaking with fear" (laughter). Not only was the governor a powerful individual, someone of higher social status, but he also belonged to a higher caste by birth. He incarnated a kind of human being that Barman felt was essentially different from a Magar shepherd. This anecdote reminds us that caste hierarchy is not only an abstract system of social classification. It was embedded in Barman's body and, for him, overcoming his initial fear was the first step towards 'political awakening'.

It soon became clear that Krishna Mukhiya had bribed the governor so that he would win the case and to ensure that Barman would stay in prison, away from the village. Barman's friends begged him to compromise: "It's useless to fight, we won't get anything that way. Krishna Mukhiya gave a bribe of Rs 3,000 [a substantial amount at the time] to the governor. Let's pay the Rs 3,000 to Krishna. He will withdraw his accusation, the case will be settled, and we will go back home." Barman stubbornly refused: "If they want to kill us, let them kill us! I shall not go anywhere until I am recognized as innocent [not a Communist].”

Although Barman and his friends were not allowed to leave the district headquarters, they were not imprisoned, unlike the well-known political leaders, Mohan Bikram Singh and his

\footnotetext{
${ }^{20}$ The Communist Party of Nepal, founded in Calcutta in 1949, was banned in Nepal until 1955, then again during the Panchayat period (1960-90) along with the other parties.
} 
friend Khagulal Gurung, who were there at the same time. ${ }^{21}$ Barman remembers hearing them shouting communist slogans two or three times a day and giving the governor a lot of trouble. He did not then know the important role that "Mohan Bikram and his people" (mohanbikramharu) were to play in his life and in the future of Thabang.

The governor eventually summoned Barman and Krishna Mukhiya to appear before him together. Lacking evidence - faced with Barman's questions his opponent remained silent, "scratching his head" - the governor issued a written statement (tamsuk) lifting the accusation of Communist involvement and treating the case as an ordinary dispute. Barman and his friends were to pay a small fine (Rs 300 for Barman, as the leader of the group, Rs 200 for his associates) as compensation for the trouble they had caused Krishna Mukhiya. Although Barman's group went back to Thabang, Barman himself refused to pay the fine and was more determined than ever to oppose Krishna. The situation was so tense that Barman's family insisted that he spend time in the pastures, away from the village. Barman turned to the other tutelary authority he knew: Upendra Bahadur Shahi, in Rukumkot, the younger brother of Indra 'Captain', Thabang's birta-holder. However, the Thakuri turned a deaf ear to Barman's complaints. For Barman, the fine of Rs 300 was not the issue. He wanted fair treatment and recognition of his innocence. It was a question of principle.

\section{Mohan Bikram Singh's visit to Thabang ${ }^{22}$}

In 1956 Mohan Bikram Singh and two friends were released from prison in Salyan. On their walk back to Pyuthan, they stopped in Thabang for a few days and introduced the villagers to the communist ideology:

They spoke about the evolution of man and about other countries in the world, about Marx and Lenin. We heard about Mao later. Communist books translated into Nepali were circulated and we were encouraged to organize a sort of commune, where everything was done collectively, cooking, eating, and working. I thought: "If educated people are in the Communist Party, why not us as well?"

\footnotetext{
${ }^{21}$ Mohan Bikram Singh, currently the leader of the CPN (Unity Center-Masal), joined the underground Communist party in 1952, organized a communist training camp in Pyuthan in 1953-54, and was jailed in 1954 for 18 months, first in Pyuthan then in Salyan.

${ }^{22}$ For complementary information, see Ogura (2007) and Gersony (2003: 25-8).
} 
Informed of the ongoing conflicts between Barman and Krishna Mukhiya, which were dividing the village into two factions, Mohan Bikram Singh persuaded them to reconcile and form a peasant association as a front organization of the banned Communist Party. The resolution of this conflict is reminiscent of the recurrent pattern found in the partly legendary and partly historical accounts of the conquest of Nepal by the Thakuris. Tribal chiefs, especially among the the Magar, would call a Thakuri king to rule over their community to end their chronic instability. In the contemporary situation, clandestine affiliation to the Communist Party acted as a temporary social binding for a divided community.

Krishna died of tuberculosis in 1958 and Barman was elected headman by the villagers in his place, a year before the first parliamentary elections. As the election approached, he was contacted by activists from the Gorkha Parishad and the Nepali Congress, who were campaigning for their parties and trying to secure votes from the villagers: "How could they work for the people when they called themselves [respectively] the Ranas' party and King's party? I did not join them." All the Thabangis voted for the Communist candidate, Khagulal Gurung, who had been visiting the village regularly since his first visit with Mohan Bikram Singh in 1956. 'Our food is maize, our weapon is the sickle ${ }^{, 23}$ went the song that celebrated the symbol of the Communist party at the time. Following the stereotype associated with ethnic communities, the unanimous voting pattern of Thabang must have been attributed to the political ignorance of backward peasants, blindly following their chief. However, the obviously strong Communist presence in Thabang also attracted the attention of the authorities.

\section{Barman's first measure as a Communist headman (1959)}

One communist teaching that Barman made his own - he says that once you are "aware", then ideas come naturally "from inside" yourself, without being imposed from outside - is that impurity is not intrinsic to people; it is only a prejudice:

Whether it is tasty or not, the tongue tells it Whether it is pure or not, the eye sees it.

\footnotetext{
23 makai hamro akar, hasiya hamro hatiyar.
} 
In a few words Barman strips the notion of impurity of its symbolic dimension in Hindu thought (all the more powerful for being invisible), and brings it down to its more prosaic version, that is, dirt. The episode of the soya beans conveys how caste hierarchy could be embodied by a young peasant like Barman, who could not at first believe what he saw (a high-caste official eating the same food as himself) and whose body shook with fear after the encounter. What the above adage now evokes, by contrast, is an enlightened person who does not blindly endorse received wisdom but rather trusts his own senses and thinks for himself.

The reforms that Barman implemented did not only concern the way Blacksmiths and TailorMusicians were treated in the village. He also allocated them uncultivated land and encouraged them to become independent of their former masters: "In Thabang the Dalits are now farmers, soldiers, or workers abroad like any other caste. People will gradually get rid of the habit of considering them impure. It is only a habit."

The other task of prime importance to Barman was the creation of a school: "I wrote a fake paper showing that we had the facilities to build and open a school. This was the government procedure to get the permission. B.P. Koirala was the Prime Minister at the time [1959] and the Nepali Congress neglected us because we were known to be Communists. But the permission was finally granted." As was common in those days, a retired soldier from the Indian Gurkha regiments was the only literate person in the village and was therefore the only available schoolmaster. Later on, Communist activists from Mohan Bikram's group in Pyuthan, came to teach in Thabang, thus securing at the same time a more systematic ideological education, notably through night classes. The school would remain an important centre of communist teaching throughout the Panchayat years. ${ }^{24}$

Barman had first been accused of being a Communist by a personal enemy, a Nepali Congress sympathizer. In the climate of village factionalism his embrace of the Communist cause looked at first more like a counterattack than a well-thought-out ideological commitment. Barman himself acknowledged the logic of affiliation to political parties among uneducated villagers:

\footnotetext{
${ }^{24}$ See Ogura (2007: 464-6) on the role of teachers in the expansion of communism in Rolpa and Rukum.
} 
There always were opposed groups (dappha) in the village. Nowadays people know more about [national] politics and join political parties. But the reasons for conflicts are the same as before. If my enemy joined one party, I would join the other one. People are motivated by anger. They are not politically aware.

Right from the beginning of the politicization of the country, old local conflicts found new names. However, in the process, the villagers became connected to a new network of relationships throughout the nation. The political parties opened avenues from the periphery of the country to its centre. Although the Panchayat years drove this process underground, it did not bring it to an end: along with new factors such as rising education and the general opening of the country to the outside world, the traditional ferment of conflict within the village kept feeding it.

\section{From underground to parliament: 1960-1991}

\section{The Panchayat years: increasing state repression leads to stronger political convictions}

This is not the place to trace all the developments of these thirty years of political life. For Barman, they were marked by several elections, both at local and national levels, by clandestine activities, and by a great deal of travelling. King Mahendra dissolved Parliament in 1960 and the first elections for the Panchayat replacement happened one year later. In the course of his many trials, Barman came to know some of the government officials quite well. One of them, Ratna Bahadur Gurung, was the Commissioner of Bheri Zone. Seeing in Barman a local leader with a career ahead of him, he tried to convince him to join the Panchayat system and to stand in the elections. Barman refused. "What would my friends from the Party say if I won? I preferred to remain a shepherd (gwala), a Communist gwala!" he said with a laugh.

Although he wanted to keep his distance from political activity in the village as long as this was a partyless democracy, the villagers, or at least a majority among them, insisted that he stand in the local elections. He duly did so in 1966 and was elected village chairman, by then called Pradhan Panch, for the second time. However, conflicts arose at the time of the following elections, when his opponent, Ram Kumar Budha, a supporter of the Panchayat system, managed to win, apparently with the help of the election commissioner. Ram Kumar 
failed to unite the Thabangis and the village was again split into two groups as in the time of Krishna Mukhiya in the 1950s. When he was not in conflict with Barman, Ram Kumar fought with Kaman Jhankri, another Communist supporter.

The 1970s were marked by several legal cases against the Communists. In 1979-1980, when a referendum on the Panachayat system was called, Barman, now Pradhan Panch for the third time, was called to Libang, the headquarters of Rolpa district, ${ }^{25}$ to campaign for the Partyless side:

Pashupati Sumshere and Khadga Bahadur K.C. held a meeting in the district hall, asking us to vote for nirdal (the Partyless system). I said that I did not know what my people would vote, nirdal or bahudal (the multi-party system): this was their choice, not mine. I was their representative and could not decide in advance. They insisted that I join them and offered me money and protection. They would act as a shield whatever I did if I went onto their side. But I refused. Other leaders looked at me and asked me to think twice, but I stuck to my position.

Then the CDO and the police inspector came to me and said that Thabang was a dangerous area with all this forest around. They asked me for a good place to build a police station. I sent them to the top of the hill, where the forest is the thickest! (laughs)

This was a declaration of war. Sure enough, Barman continued, Thabang unanimously voted for the multi-party system in May 1980, then boycotted the general elections one year later. The police station was established in the course of a major operation in October 1981. Barman was arrested on a false charge of gambling, which followed a set-up in a teashop. Jailed for twenty days, he was finally declared innocent, but was arrested again, this time under the Public Security Act (which allowed detention without trial for up to twelve months) and spent another seven months in a prison in Libang. He was transfered to Gorahi, the headquarters of neighbouring Dang district, where his detention was extended to twenty months for an anti-state crime that he supposedly committed in Thabang... while he was in jail: "I'm not a bird that can fly!" This was because of an episode that soon became a legend: the burning of the portrait of King Birendra and Queen Ishwara in the Panchayat office of Thabang. Barman was presented as the culprit, although the damage to the portrait in fact occurred in the course of a fight between the vice-chairman of the village, a Panchayat

\footnotetext{
${ }^{25}$ Rolpa was separated from Pyuthan and became one of Nepal's 75 districts in 1961.
} 
supporter, and a Communist villager. ${ }^{26}$ What is certain is that a picture of the late king and his family occupied a place of honour in Barman's Kathmandu house until the 2006 uprising, when the prospect of a republic buried the memory of the vanished royals in an irrelevant past.

\section{Knowledge acquired in prison: From Volga to Ganga}

Barman's arrests are like a serial, one episode followed by another in an endless game of hide-and-seek that never leaves him defeated. On the contrary, acts of state repression could not but strengthen his convictions. Barman also acquired knowledge in prison. This is how he came across a book in Hindi about the evolution of man "from the time people lived in caves up to Nehru". Although Barman could not identify this book - the title and the author's name had been lost with the cover - what he remembered was enough to suggest that this was From Volga to Ganga, by Rahula Sankrityayana. ${ }^{27}$ This is the only book that Barman mentioned in greater detail than the vague and dutiful references to Marx and Lenin, and it may be useful to say a few words about it. It was published in November 1943 and was so successful that a second edition was published a year later, followed by an English translation in 1946. The author, who was Professor of Indology at Leningrad University in the 1930s, popularized a history of humanity through narratives heavily impregnated with communist ideology.

The book develops nineteen stories based on different characters, each representative of his or her time. The first chapter describes a small band of blood-related kin around the mother, Nisha, living by hunting on the upper banks of the Volga. The story revolves around the matriarchal state of society at the dawn of humanity, when the necessity of survival in a hostile environment did not allow human sentiments. The descendants of this primordial mother developed into an Aryan clan and migrated towards the East and India through the Himalayas. The last chapter takes place in 1922 and is based on a conversation between two intellectuals: Sofdar, a young and successful lawyer, and Shankar, his friend from

\footnotetext{
${ }^{26}$ In an earlier publication (de Sales, 2000), I myself took for granted the account that I heard in the neighbouring village of Lukum, a little more than a year after the event. This false rumour reveals how striking for the imagination any sacrilegious act against the king was at the time.

${ }^{27}$ I thank Dilip Menon for this suggestion at the Oxford conference where I presented a first version of this paper. After I read the book myself, I was able to confirm that some of the stories matched Barman's memories.
} 
schooldays, a more modest schoolteacher. They discuss the issue of Indian independence within the context of European revolutionary history and Shankar puts forward the shortcomings of Gandhi's peaceful resistance. Sofdar is deeply moved by this conversation and decides to abandon his property along with the British lifestyle that he and his wife have enjoyed so far. The couple join the movement for independence in a communist cell.

Barman may not have been familiar with European history and the urban intellectual milieu, on which the last chapters of the book are based. However the narrations skilfully provided a number of received wisdoms that Barman still enjoys checking against his own experience. He agreed, for instance, that, unlike plains people, 'Mongolian' hill tribes are brave warriors and like cold places. The evolutionist perspective developed throughout the nineteen chapters of the book appeared as a natural truth to him. In the process of reading these overviews on the history of humanity, he acquired the ability to reorganize his own experience of time and to view the current political situation in a long-term perspective. He presumably also saw himself as playing a progressive role in this historical human saga.

\section{'Addiction' to politics and the question of the common good}

During his stay in prison Barman also reflected on his fellow prisoners. They were people from various castes and origins, whom he describes as being all "addicted" (nasa) to something, whether it was to alcohol and women, to money like thieves and businessmen, to religion like the Christians, or to politics like himself. They could not help doing something that in the end was dangerous and possibly destructive, something stronger than practical reason, but that would drive them irresistibly and that, in the end, they enjoyed. If personal suffering or frustration trigger one's commitment to political action - "until people are caught (by the police), they know nothing; until they go to jail and suffer, they are afraid of everything, they are not aware" - it seems that the experience of overcoming this suffering through resistance and struggle fuels the feeling of one's own power. This feeling grows all 
the more as the reason for resistance is the pursuit of the common good and no longer solely one's own benefit. ${ }^{28}$

Barman likes to repeat that he was not involved in political activities through personal interest, but because he was representing the people. However, it is worth noting that in expressing his political programme and general vision of society, he never used the patronizing or moralizing style of the standard activist discourse (whether of social or political activism, Panchayat, or Communist). This style, forged over the last fifty years of schooling and the dominant development ideology, conveys a conception of villagers as backward people waiting to be civilized. ${ }^{29}$ As mentioned earlier, Barman was sent to high pastures with the sheep from an early age and did not receive any formal education. Although he can read and write - reading newspapers is his "daily prayer" - he is not an intellectual alienated from his own society. ${ }^{30}$ In this sense, he has remained closer to being a local leader, preoccupied more by his people's welfare than by conforming to universal ideals. His independent spirit can be discerned from the way he relates the adventure of the first parliamentary elections in 1991.

\section{The 1991 elections}

Once the ban on political parties was lifted in 1990, an active campaign for the first general elections started on all sides. It must have been clear for the leaders of the United People's Front that Barman was a key candidate likely to achieve success in Rolpa. He was therefore asked to run for the Party. It was agreed that he should compete against Bala Ram Gharti Magar, the Rastriya Prajatantra Party's strong candidate,in the eastern constituency of Rolpa, even though this was not Barman's own home base. At the same time he could mobilize the western constituency - his own - where another candidate, Krishna Bahadur Mahara, would benefit from his support. Barman hesitated at first:

\footnotetext{
${ }^{28} \mathrm{On}$ the basis of interviews with Maoist activists, Fujikura (2003) developed the idea that joining the movement was not simply a reaction to personal grievances, but to the aspiration to "bring about a particular form of collective future".

${ }^{29}$ See Shneiderman, this volume. For a general analysis of the development ideology and its reception by villagers, see Pigg (1992).

${ }^{30}$ On this subject, see Krauskopff (in press).
} 
I was already old (61 years) and I thought that a younger person would do better. But the UPF leaders insisted. I wanted to walk alone [i.e., not with the entourage that candidates usually recruit during their campaigns]. I went everywhere in the eastern part of Rolpa. I stayed in all the houses, whatever their party was, and whatever their caste was. I would eat there and tell them that although I was fighting for the UPF, they should think about this by themselves and vote for whichever side they thought was better. I would go and see them at work, share their tasks, carry their children, beat the grain, or plough a length of field. I am also a farmer, aren't I? I would joke and say, "You are from another party, but I know that you will end up voting for me!" It was on the radio that I heard that I'd won - I did not go to the headquarters for the counting of the votes. Bala Ram went with his supporters and they tried to cheat. They thought it was still the way it had been under the Panchayat. I went later though and shook hands with him. This is only politics [not personal].

Looking at his campaign from the point of view of marketing and the public image industry, Barman appears to have played the card of authenticity and simplicity. He initiated a style of public relations totally different from the more solemn and hierarchical behaviour usually adopted by politicians and government officials. With nobody to carry his bag or umbrella, Barman walked from village to village armed only with his convictions. He sustained this attitude all the way to Singha Darbar, where the new Parliament met, in Kathmandu. This is the setting of another legend about Barman and, unlike the episode of the burning of the royal portrait, one with a solid foundation.

\section{The first meeting of Parliament and the question of ethnicity}

When I arrived in Kathmandu, my friends [Party supporters] insisted that I change my village dress - the short kilt and the velvet shirt - for the Nepali dress of daura suruwal. I refused, accepting only to wear a jacket on top. Then we were called to Singha Darbar in order to prepare the visit of the king the following day. He was coming with the queen to give a speech before the first meeting of the Parliament. The general secretary took me to one side and told me: "You have to wear the national dress for the king's visit tomorrow". I told him: "What I am wearing now, I have always worn and so did my ancestors. If I can't wear this in front of the king, then why should I stay here? I don't mind going back to the village." The general secretary did not reply. The following day there were a lot of people, everybody with the same dress and the same grey jacket. We were standing in line as the king and the queen walked by us. The king noticed me, a little surprised maybe, but he did not say anything. He gave his speech and all went fine. 
Barman's brevity about this episode stands in stark contrast to the extensive public comment the incident generated. How are we to understand his eccentricity on this point? In the general context of the 1991 elections, the ethnic issue provides an obvious first interpretation of what looked like a provocative stand against the dominant Nepali culture, which minorities began to question openly. ${ }^{31}$ However, not once in the course of our discussions did Barman claim to represent Magar culture or identity, nor did he claim to be fighting for it. As a matter of fact, mention of ethnic protest was remarkably absent from his discourse. At this point we are left with speculations, and a glance at the Communist position towards minorities may be useful.

Mukta Tamang reminds us that in 1951, just two years after it was founded, the Communist Party of Nepal (CPN) issued clear statements in favour of "the preservation of cultures, the development and fundamental rights of all castes and ethnic groups...their inclusion in governance and use of mother tongues in education and local bodies". ${ }^{32}$ In the following decades, however, the Party focused on 'class struggle' to solve social problems at the same time as it promoted a strong nationalism to fight imperialism. The Communists counted only a few people from ethnic communities and even fewer were influential within the Party. According to Tamang, these leaders ended up leaving the Party out of frustration and embarked on new political career, some of them along ethnic lines, such as the Magar, Gore Bahadur Khapangi (see below). Even when, in the post-1990 period, the Communists reconsidered their position towards culture, caste, and ethnicity, they saw the ethnic movements and their extremist trends as reactionary, bringing Nepal back to the preunification stage.

Tamang argues that the Maoists departed from these ideological premises shared by most on the left and were able to assess the post-1990 political situation and aspirations of the people in a more pragmatic way: "Instead of condemning caste/ethnic based movements ... the

\footnotetext{
${ }^{31}$ Barman was one of a number of new MPs who took the oath of allegiance in their mother tongue, not in Nepali, which was likewise much commented on. It is interesting however that Barman never mentioned this himself.

${ }^{32}$ Report from the first CPN conference in 1951 in Calcutta, quoted in Tamang (2006: 274).
} 
CPNM has come to recognize (them) as necessary allies" (Tamang, 2006.: 284). ${ }^{33}$ One of the main reasons for the increasing Maoist support for the ethnic agenda was the important role played by indigenous nationalities in advancing the armed struggle. In 2001, as the guerrilla warfare intensified, the Maoist 14-point programme publicly stressed equality and freedom of the oppressed nationalities and their right to self-determination. Three years later, within the space of a month, they declared nine 'Autonomous Regions', six of which had an ethnic basis, starting with Magarant on $9^{\text {th }}$ January 2004.

The Athara Magarant provided the Maoists with a case in point for their ethnic politics. As mentioned above, Kham speakers are a linguistic minority within the Magar group and the Magar elite involved in ethnic issues looked down on them. The Nepal Magar Sangh, founded in 1991, did not count a single Kham speaker in its offices until 1998. For Gore Bahadur Kapangi, secretary of the association at the time, the general lack of education on the part of the Athara Magars (another way of referring to Kham speakers) explained why it was difficult to mobilize them on ethnic issues. The Maoists, by contrast, knew how to make good use of an area neglected by Magar activists. In 2002, they singled out the fourteen Kham-speaking Village Development Committees as a 'special district' that would be added to the 75 others created under the Panchayat administration. The Athara Magarant and the obsolescent 'residual heights' of the Kalashes and Gorashes had become the core of the future Autonomous Magarant Region. The chief of the Magarant People's Government, Santos Budha Magar from the village of Thabang, was elected by the Magarant Parliament on the eve of the official declaration of the Magarant Autonomous Region. ${ }^{34}$ In this way, with Maoist support, the Athara Magarant stole the show on the ethnic scene that had previously been dominated by the Bahra Magarant.

This being said, if the Maoists have courted the indigenous populations and acknowledged that they had been 'historically oppressed' by the Indo-Aryans, their ultimate goal was

\footnotetext{
${ }^{33}$ See also Lecomte-Tilouine's (2004) analysis of ethnic demands in the Maoists' discourse between 1990 and 2001. She brings out the contradictions inherent to the questions of territorial autonomy, nationality, and class with a special focus on Magar activists at the revolutionary end of the spectrum.

${ }^{34}$ For a detailed account of the formation of the Magarant Autonomous Region, see Ogura (2008).
} 
always the building of a nation of equal citizens. Santos Budha Magar was very clear on this point:

We Communists are not jatibadi (supporters of nationalitism); our final purpose is to delete the concept of jati (nationalities) and classes and to make all people samyabad (supporters of equality). However, as our society is half way between feudalism and capitalism, we formed the Autonomous Region as a stage to change the people's consciousness. (Ogura, 2008: 201)

The recognition of ethnic nationalities as distinct cultural-political entities, and the right of these nationalities to self-determination, are seen as a transitional phase in the evolutionary process of economic development and cultural assimilation. According to this view, the contradictions inherent in the historical situation will be resolved in the course of time, when education gradually changes people's consciousness.

The recently elected Constituent Assembly is still working on the new constitution and it is too early to make any predictions about the outcome of the ethnic policy of the Maoists who are now the dominant force in the government.. For the time being, the autonomous regions and all the other levels of Maoist 'people's government' that were established during the last years of the People's War are officially abolished. This incursion into the subject was an attempt to clarify Barman's aloofness towards ethnic issues in 1991. We might conclude that his attitude reflected his party's line, one that was already fraught with contradictions, but he had his own way of overcoming them. He did not politicize his identity as a Magar, but his wearing Magar dress in Parliament and taking the oath in Kham made it clear that he had not abandoned it either.

\section{Conclusion}

At the risk of succumbing to the 'biographical illusion' (Bourdieu, 1994), the dress incident in Parliament may be seen as the outcome of a long process that started thirty-seven years earlier in Pyuthan, during Barman's encounter with the governor. When the quarrelsome young shepherd reached Pyuthan headquarters for the first time with his friends from Thabang, he was out to win. Falsely accused by his village enemy of being a Communist, he 
wanted to right a wrong. However the sight of the men in suruwal made him and his friends run away out of fear and the presence of the governor got the better of Barman's body, which shook for days afterwards. Nevertheless, this traumatic encounter was also the source of a revelation - the governor was not a demigod but an ordinary human being who ate soya beans like everyone else - that marked the beginning of Barman's career as a political actor. Once he had overcome his fear, Barman felt empowered to fight injustice. The meeting with Mohan Bikram Singh was a turning point in his career and the teachings of the Communist activists provided him with the conceptual tools and the political infrastructure to frame village disputes in terms of a national political struggle. Within a few years the young man whose family had kept him away from home to avoid trouble became the Communist leader of his village, determined to go beyond running village affairs.

It seems that the empowerment Barman associates with the accusation of communism was of a different kind from his earlier wish to fight his long-term village opponent. What Barman calls chetan, 'consciousness' or 'awakening', is the key to a total transformation of the self, something potentially dangerous because it leads to transgressions, but enjoyable nevertheless and even intoxicating. Barman speaks of "addiction to politics" (rajnitik nasa). Although this inner transformation brought about a certain level of reflexivity in Barman's vision of himself, it did not alienate him from his own society: on the contrary, as suggested above, in this respect he remained closer to a traditional local leader than an activist.

In his biography of Tanka Prasad Acharya, the founder of the first Nepalese political party, James Fisher suggests that "the special role of Brahmins is central to the construction of power and agency in Nepal". The Brahmins could not be executed "not just because it was illegal but because it would have been too great a sin to have done so" (Fisher, 1997: 253-4). Although the Brahmins may have had to face physical duress - and they did - the charisma of their caste supported them in the process of their political empowerment. Barman could not rely on such a privilege. Indeed, he had to draw his power from some other source of legitimacy, and for this he turned towards his ancestors. There was no ostentation in Barman's behaviour in Parliament. He was simply being who he was, a representative of the rural population that had so far been too remote, poor, and uneducated to be present among the men in suruwal. 


\section{References}

Aziz, B. 2001. Heir to a Silent Song: Two Rebel Women of Nepal. Kirtipur: Centre for Nepal and Asian Studies.

Bourdieu, P. 1994. 'L'illusion biographique', ch. 3 in P. Bourdieu Raisons pratiques: Sur la théorie de l'action. Paris: Seuil.

Fisher, J.F. 1997. Living Martyrs: Individuals and Revolution in Nepal. Delhi: Oxford University Press.

Fujikura, T. 2003 'The Role of the Collective Imagination in the Maoist Conflict in Nepal', Himalaya, 23(1): 21-30.

Gaborieau, M. 1978. 'Le partage du pouvoir entre les lignages dans une localité du Népal Central', L'Homme, 18 (1-2): 37-67.

Gellner, D.N. and M.B. Karki 2007. 'The Sociology of Activism in Nepal: Some Preliminary Considerations', in H. Ishii, D.N. Gellner, and K. Nawa (eds), Political and Social Transformations in North India and Nepal, Delhi:Manohar, pp. 361-97.

Gersony, R. 2003. 'Sowing the Wind...History and Dynamics of the Maoist Revolt in Nepal's Rapti Hills' (report submitted to Mercy Corps International, October 2003), available at www.un.org.np.

Hachhethu, K. 2006. Political Parties of Nepal, Kathmandu: Social Science Baha Occasional Papers.

Joshi, B.L. and L. Rose 1966. Democratic Innovations in Nepal: A Case Study of Political Acculturation. Berkeley: University of California Press.

Koirala, B.P. 2001. Atmabrittanta: Late Life Recollections. Kathmandu: Himal Books.

Krauskopff, G. (in press). 'Intellectuals and Ethnic Activism: Writings on the Tharu Past', in D. Gellner (ed.), Ethnic Activists and Civil Society in South Asia. Delhi: Sage, pp. ****.

Lecomte-Tilouine, M. 2000. 'The Enigmatic Pig. On Magar Participation in the State Rituals of Nepal', Studies in Nepali History and Society, 5 (1): 3-41. 
Lecomte-Tilouine, M. 2004. 'Ethnic Demands within Maoism: Questions of Magar

Territorial Autonomy, Nationality and Class', in M. Hutt (ed.), Himalayan 'People's

War': Nepal's Maoist Rebellion. London: Hurst \& Company, pp.112-35.

Lecomte-Tilouine, M. (in press). 'Ruling Social Groups - From Species to Nations:

Reflections on Changing Conceptualizations of Caste and Ethnicity in Nepal', in D.N.

Gellner (ed.), Ethnic Activists and Civil Society in South Asia. Delhi: Sage, XXXX

Levy, R. 1998. 'Selves in Motion', in D. Skinner, A. Pach III, and D. Holland (eds), Selves in

Time and Space: Identities, Experience, and History in Nepal. Lanham: Rowman \&

Littlefield Publishers, pp. $* *_{-} * *$.

March, K. 2002. 'If Each Comes Half Way': Meeting Tamang Women in Nepal. Cornell University Press.

Minami, M. 2007. 'From Tika to Kata?: Ethnic Movements among the Magars in an Age of Globalization', H. Ishii, D. Gellner, K. Nawa (eds), Nepalis Inside and Outside Nepal, Delhi: Manohar, pp.443-66.

Ogura, K. 2007. 'Maoists, People, and the State as seen from Rolpa and Rukum', in H. Ishii, D.N. Gellner, and K. Nawa (eds), Political and Social Transformations in North India and Nepal, Delhi: Manohar, pp. 435-75.

Ogura, K. 2008. 'Maoist People's Governments, 2001-05: The Power in Wartime', in D. N. Gellner and K. Hachhethu (eds), Local Democracy in South Asia: Microprocesses of Democratization in Nepal and its Neighbours. Delhi: Sage, pp. 175-231.

Pigg, S. L. 1992. 'Inventing Social Categories Through Place: Social Representations and Development in Nepal', Comparative Studies in Society and History, 34(3): 491-513.

Pokhrel, D. \& D. Willett 1996. Shadow over Shangrila: A Woman's Quest for Freedom. Dulles: Brassey's.

Sales, A. de. 2000. 'The Kham-Magar Country, Nepal: Between Ethnic Claims and Maoism', European Bulletin of Himalayan Research, 19: 41-72. Also published in D.N. Gellner (ed.) 2003. Resistance and the State: Nepalese Experiences. Delhi: Social Science Press, and in D. Thapa (ed.) 2003. Understanding the Maoist Movement of Nepal Kathmandu: Martin Chautari.

Sales, A. de. 2003. 'Remarks on Revolutionary Songs and Iconography', European Bulletin of Himalayan Research, 24: 5-24. 
Sankrityayana, R. 1947. From Volga to Ganga: A Picture in Nineteen Stories of the Historical, Economic and Political Evolution of the Human Society from 6,000 BC to 1922 AD. Bombay: People's Publishing House, Ltd.

Tamang, M. 2006. 'Culture, Caste and Ethnicity in the Maoist Movement', Studies in Nepali' History and Society, 11(2): 271-301.

Thapa, D. (ed.). 2003. Understanding the Maoist Movement of Nepal. Kathmandu: Martin Chautari.

Whelpton, J. 2007. A History of Nepal. Cambridge: Cambridge University Press. 